\title{
THE URBAN POOR AND LIVELIHOOD VULNERABILITY: ARE GENDER, AGE AND MARRIAGE INTERTWINED?
}

\author{
Fouzia Mannan*
}

\begin{abstract}
Dhaka is the capital city and the single fastest growing metropolis in Bangladesh by 2020 its population will have increased thirty-fold to over ten million. This rapid population growth is largely facilitated by mass rural-to-urban migration. The speed of urbanization and the enormous numbers involved make it one of the major development challenges of the 21st century (World Bank \& Bangladesh Centre for Advanced Studies, 1998). Neither public nor private facilities can meet the basic human needs (food, water, shelter, sanitation, and a safe environment) of slum dwellers, most of whom also lack livelihood security. To understand the magnitude of urban poverty, this research explores the question of whether gender, age and marital status are indeed linked to livelihood vulnerability among the urban poor. It has utilized qualitative methods of data collection -FGDs, case studies (based on in depth-interviews) and participant observation from a selected slum in DhakaBegultila. Results of this study has indicated that both physical and emotional vulnerabilities have a crucial impact on the livelihood pattern of the slum dwellers of Begultila. To understand the state and nature of poverty in Begultila it is important to consider non-economic factors, which have a very strong role in enhancing vulnerability among the urban poor, particularly with children, women, and the elderly. This study sheds new light on urban poverty in relation to livelihood vulnerability; and consequently, highlights the diverse experiences of the urban poor and the livelihood insecurity that automatically categorizes them as one of the most vulnerable groups within the slum community. This form of livelihood vulnerability has a crucial effect on the nature and quality of life of the urban poor, particularly for women, which in turn, perpetuates the cycle of poverty.
\end{abstract}

Keywords: urban poor, gender and livelihood vulnerability

\section{Introduction}

Bangladesh has experienced rapid rates of urban growth over the last three decades. The capital city of Dhaka is the single fastest growing metropolis - by

\footnotetext{
* Fouzia Mannan, PhD is Professor, Department of Sociology \& Dean, Faculty of Liberal Arts and Social Sciences, East West University, Dhaka, Bangladesh. Email: fouziamannan@gmail.com

Social Science Review [The Dhaka University Studies, Part-D], Vol. 37, No. 2, December 2020
} 
2020 its population will have increased thirty-fold to over ten million in the last 30 years. Within the Bangladeshi population only 9 percent lived in urban areas in 1974; by 2011 this proportion had reached 28 percent and continues to increase substantially; according to recent population projections from UNDP, between about 46 and 60 million are likely to be added to Bangladesh's population between 2011 and 2041 alone (Afsar, 1998). Given current trends, the national population is expected to become predominantly urban in roughly three decades, accompanied by the mushrooming of slum and squatter settlements (World Bank, 2007). The rapid population growth is increasingly fuelled by mass rural-urban migration and neither public nor private facilities can meet the basic needs (food, water, shelter, sanitation, and a safe environment) of slum dwellers, most of whom lack livelihood security. (Joshi, Fawcett, \& Morgan, 2005). Most government authorities ignore the slum settlements and very often resist initiatives to improve services to the slum residents. The poorest amongst the urban poor, the homeless, are often outlawed and deemed illegal by governments and hounded by 'legal' urban residents for forming scabs in 'their' cities (Joshi, Fawcett, \& Mannan, 2011).

According to the World Bank's approximate, current and future estimates of the number of people living in urban centres, "the speed of urbanization and enormous numbers involved not only will be increasingly important determinants over time of national welfare and performance on the Sustainable Development Goals (SDGs) but also make it one of the major development challenges of the 21st century" (World Bank, 2007, p 47).

A phenomenon that has been observed in recent years in developing countries is that women disproportionately bear the burden of poverty and are thus, more likely to fall into the poverty trap at a faster rate than men. In Bangladesh, women are falling below the poverty line at an increasing rate and number; more women are now living in hard-core poverty than men. It appears that the phenomenon called 'feminization of poverty' is rapidly assuming alarming proportions in Bangladesh, (Salahuddin, 1997).

Nonetheless, foremost research by Kabeer and Mahmud (2004) and Mahmud (1997) have also found a trend in current urbanization patterns in Bangladesh females between the ages of 15-29, are migrating from rural to urban areas for better income opportunities and a large number are find themselves subject to sexual harassment and unequal treatment causing insecurity both in the public 
and private sphere (United Nations Population Fund [UNFPA], 2016). These changes have added a new dimension to the essence of urban poverty in Dhaka.

Hence, to understand the magnitude of urban poverty, this study aims to examine and explore the questions of whether gender, age and marital status are linked to livelihood vulnerability among the urban poor. In this context, this study will explore the diverse experiences of the urban poor in general and women, elderly and children in particular in relation to livelihood vulnerability in an urban slum in Dhaka.

\section{The Urban Poor and Livelihood Vulnerability: Concepts and Issues}

Research on urban poverty in the 1990s, consisted of several researchers and development agencies developing a livelihoods approach, the quest of building a more appropriate conceptualization of urban poverty in relation to the diverse experiences of the urban poor. These approaches emphasized on the capabilities and assets of the poor, rather than their problems and lacking. Rakodi and Lloyd (2002, p7), for instance, defined "the 'livelihoods' concept as a realistic recognition of the multiple activities in which households engage to ensure their survival and improve their well-being (see also Ellis, 1998)". This concept can be understood more effectively if approached from the perspective of the povertystricken themselves; the nature of this approach allows poverty to be contemplated as multi-dimensional, diverse, and more importantly as malleable or sensitive to changes in society.

Correspondingly, Chambers and Conway (1992) have given a more focused definition of livelihood as a combination of the 'capabilities, assets (including both material and social resources) and activities required for a means of living' (Carney, 1998, p4). While utilizing the livelihood approach it is important to understand that the 'poor may not have cash or other savings, but they do have other material or non-material assets' - health, labour, social networks, knowledge and skills. According to Rakodi and Lloyd (2002) household livelihood assets are human capital, social and political capital, Physical capital, financial capital, and natural capital (Rakodi \& Lloyd, 2002, p.11).

The concept of vulnerability is fairly recent, within the discourse on poverty. In analysing the concepts of asset and sources of vulnerability, Walker, Ramasut and Farrington (2002) argued that "assets are the resources on which people draw to carry out their livelihood strategies. These resources include a broad range of financial, human, social, physical, natural, and political capital. Assets are not 
always owned by the men and women who use them in their livelihood strategies - rather, they may have varying extents of access to and control over these assets" (Walker, Farrington, \& Ramasut, 2002).

Nonetheless, livelihood vulnerability is explained by Rakodi and Lloyd, (2002, p.11), Farrington and Robinson (2006) as 'the insecurity or wellbeing of individuals or communities in the face of changing environments (ecological/social/economic/ political) in the form of sudden shocks, long term trends or seasonal cycles' (Moser, 1998; Walker et al., 2002; Rakodi \& Lloyd, 2002).

To understand the sources of vulnerability, then it can be argued that "it is necessary to analyse trends (resource stocks, demographic change, available technologies, political representation and economic trends), shocks and culture (as an explanatory factor in understanding how people manage their assets and livelihood choices they make)" (Carney, 1998; Rakodi \& Lloyd, 2002).

However, till date, poverty research has mostly dwelt on economic or nutrition related variables. Non-economic perspectives get less attention among researchers and academics, with few employing a holistic approach and an integrated analysis in studying the urban poor. Consequently, the lack of sufficient data pertaining to this field means that the conditions of life and livelihoods of the urban poor are not well understood, as most studies have narrowly focused on either socio-economic or public health issues (Islam, 1996; Islam, Haq, \& Rahman, 1996, Majumder, 1996; Afsar, 2000; Wood, 1998). Therefore, this study will attempt to shed light on the sources of vulnerability for the urban poor with a special focus on gender, which will help understand the diverse dynamics of urban poverty in South Asia.

The asset vulnerability framework (AV), according to Moser, include "both tangible assets, such as labour and human capital, less familiar productive assets, such as housing, as well as intangible assets, such as household relations and social capital. She added that the poor are managers of complex asset portfolios and illustrate how asset management affects household poverty and vulnerability" (Moser, 1998).

Livelihood vulnerability, which incorporates non - economic dimensions, is a crucial component of poverty among the urban poor. Thus, the aim of this research is to understand the urban poverty in relation to gender, age, and marital status to get a critical understanding of the magnitude of urban poverty 
considering the livelihood vulnerability framework. Hence, this research was based solely on qualitative methods and aims to develop a deeper understanding of livelihood vulnerability in terms of gender, age, and marital status

\section{Objective of the study}

The aim of this paper is to examine the relationship between selected variables (age, marital status and gender) and livelihood vulnerability, which is operationalized by occupation, shelter, infrastructure, social capital, Intra $\mathrm{HH}$ relationship and state agencies in Begultila Slum.

\section{Methodology}

This paper stems from a field - based experience in Begultila, a slum, located in Mirpur, a middle-class neighbourhood in Dhaka. Qualitative methods of collecting data have been used for the purpose of this study. This is as noneconomic indicators such as socio-cultural issues including gender, aging and marriage related vulnerability can be understood more effectively through qualitative collection techniques. Gender, age, and marriage have been selected as the key indicators of urban poverty and purposive sampling has been used to fully understand the depth and dimension of vulnerability of the urban poor. Thus, this research delved into demographic variables - age, marital status and gender perspectives with five indicators - occupation, shelter, infrastructure, social capital, intra household relationships and weak state agencies (Rakodi \& Lloyd, 2002) with the understanding that it will help to comprehend the dynamism of urban poverty in slums. Based on the in-depth interview guideline information on Begultila slum was collected using the following techniques:

- Focus group discussion/s (FGD) (15)

- In-depth interviews (20)

- Case studies (10)

- Key informant interviewing (7), and

- Participant observation.

This research also delved into demographic variables - age, marital status and gender perspectives with five indicators - occupation, shelter, infrastructure, social capital, intra household relationships and weak state agencies (Rakodi \& Lloyd, 2002) with the understanding that it will help to comprehend the dynamism of urban poverty in slums. 
Table 1: Selected indicators of vulnerability by Gender

\begin{tabular}{|c|c|c|c|c|}
\hline \multirow{2}{*}{\begin{tabular}{|c|} 
Selected \\
indicators of \\
Vulnerabilities \\
\end{tabular}} & \multicolumn{2}{|c|}{ Gender } & \multirow[t]{2}{*}{ Differentiations } & \multirow[t]{2}{*}{ Comments } \\
\hline & Male & Female & & \\
\hline \multirow[t]{3}{*}{$\begin{array}{l}\text { Income/ } \\
\text { occupation }\end{array}$} & $\begin{array}{l}\text { Joblessness / lack } \\
\text { of "secured" job } \\
\text { opportunities }\end{array}$ & $\begin{array}{l}\text { Lack of a regular } \\
\text { income of male } \\
\text { members of the } \\
\text { HH }\end{array}$ & $\begin{array}{l}\text { Gender division of } \\
\text { labour persists, } \\
\text { even among the } \\
\text { beggars. }\end{array}$ & \multirow[t]{3}{*}{$\begin{array}{l}\text { 'Feminizati } \\
\text { on of } \\
\text { Poverty' }\end{array}$} \\
\hline & \begin{tabular}{|l|} 
Lack of \\
occupational \\
frontiers \\
\end{tabular} & $\begin{array}{l}\text { Inadequate HH } \\
\text { earning member }\end{array}$ & - Dowry & \\
\hline & Lack of capital & & $\begin{array}{l}\text { Poverty-an } \\
\text { emotional crisis for } \\
\text { women. }\end{array}$ & \\
\hline Shelter & $\begin{array}{l}\text { Threats of } \\
\text { eviction }\end{array}$ & $\begin{array}{l}\text { Absence of } \\
\text { permanent } \\
\text { settlement }\end{array}$ & - Threats of violence & \begin{tabular}{|l} 
Women are \\
more \\
insecure \\
\end{tabular} \\
\hline \multirow[t]{2}{*}{ Infrastructure } & $\begin{array}{l}\text { Lack of basic } \\
\text { services }\end{array}$ & $\begin{array}{l}\text { Poor sanitation and } \\
\text { water availability }\end{array}$ & $\begin{array}{l}\text { Additional burden } \\
\text { to collect water and } \\
\text { poor sanitation }\end{array}$ & \multirow[t]{2}{*}{$\begin{array}{l}\text { Gender } \\
\text { Division of } \\
\text { Labour }\end{array}$} \\
\hline & $\begin{array}{l}\text { Poor } \\
\text { communication }\end{array}$ & & & \\
\hline \multirow[t]{3}{*}{ Social capital } & $\begin{array}{l}\text { Lack of skill for } \\
\text { work }\end{array}$ & \begin{tabular}{|l|} 
Lack of basic \\
services compared \\
to rural areas
\end{tabular} & $\begin{array}{l}\text { Male dominance } \\
\text { both in private and } \\
\text { public spheres }\end{array}$ & \multirow{3}{*}{$\begin{array}{l}\text { Women } \\
\text { controlled } \\
\text { by } \\
\text { Patriarchy }\end{array}$} \\
\hline & \begin{tabular}{|l|} 
Absence of \\
Community \\
Based Org. (CBO) \\
\end{tabular} & $\begin{array}{l}\text { Health hazards of } \\
\text { earning members }\end{array}$ & & \\
\hline & $\begin{array}{l}\text { Corruptions of } \\
\text { slum leaders }\end{array}$ & $\begin{array}{l}\text { Corruptions of } \\
\text { slum leaders }\end{array}$ & & \\
\hline \multirow[t]{3}{*}{$\begin{array}{l}\text { Intra-HH } \\
\text { relationship }\end{array}$} & - & $\begin{array}{l}\text { Intra household } \\
\text { relationship } \\
\text { deteriorated }\end{array}$ & - Domestic violence & \multirow{3}{*}{$\begin{array}{l}\text { Women are } \\
\text { prime } \\
\text { victim of } \\
\text { HH } \\
\text { violence }\end{array}$} \\
\hline & & $\begin{array}{l}\text { Absence of male } \\
\text { support }\end{array}$ & \begin{tabular}{|l|} 
Marital \\
vulnerability \\
(single hood, co- \\
wives, financial \\
exploitation)
\end{tabular} & \\
\hline & & $\begin{array}{l}\text { Irregular income } \\
\text { of male members }\end{array}$ & - Minor children & \\
\hline \multirow[t]{4}{*}{$\begin{array}{l}\text { Weak State } \\
\text { agencies }\end{array}$} & $\begin{array}{l}\text { Harassments by } \\
\text { the state agencies }\end{array}$ & $\begin{array}{l}\text { Corruption of } \\
\text { police }\end{array}$ & $\begin{array}{l}\text { - Threats of local } \\
\text { mastans }\end{array}$ & \multirow{4}{*}{$\begin{array}{l}\text { Again, } \\
\text { patriarchal } \\
\text { state } \\
\text { attitudes } \\
\text { make } \\
\text { women } \\
\text { more } \\
\text { vulnerable }\end{array}$} \\
\hline & $\begin{array}{l}\text { Coercion of } \\
\text { Mastans (Mafias) } \\
\end{array}$ & $\begin{array}{l}\text { - Threats of local } \\
\text { mastans }\end{array}$ & - Restricted mobility & \\
\hline & & & $\begin{array}{l}\text { Corruption of } \\
\text { police and }\end{array}$ & \\
\hline & & & $\begin{array}{l}\text { No access to social } \\
\text { services of the State }\end{array}$ & \\
\hline
\end{tabular}


Table 2. Selected indicators of Vulnerability by Age

\begin{tabular}{|c|c|c|c|}
\hline $\begin{array}{c}\text { Selected } \\
\text { indicators of } \\
\text { Vulnerabilities } \\
\end{array}$ & Children & Old & Comments \\
\hline $\begin{array}{l}\text { Income/ } \\
\text { occupation }\end{array}$ & $\begin{array}{l}\text { Lack of work } \\
\text { Child headed HH } \\
\text { Exploitation of girl child } \\
\text { Lack of job } \\
\text { No income } \\
\text { No food and clothing. } \\
\text { Absence of father/ male } \\
\text { members of the household }\end{array}$ & $\begin{array}{l}\text { Age is a factor to } \\
\text { get a job } \\
\text { Lack of income }\end{array}$ & $\begin{array}{l}\text { Among children, girls } \\
\text { are more vulnerable. } \\
\text { On the other hand, } \\
\text { among the old women } \\
\text { are exploited more. }\end{array}$ \\
\hline Shelter & - Threats of evictions & $\begin{array}{l}\text { Vulnerability } \\
\text { regarding shelter }\end{array}$ & Less coping capacity \\
\hline Infrastructure & $\begin{array}{l}\text { Inappropriate sanitation for } \\
\text { children } \\
\text { Extra burden of collecting } \\
\text { water }\end{array}$ & $\begin{array}{l}\text { Long queue for } \\
\text { latrine } \\
\text { Extra burden of } \\
\text { collecting water } \\
\end{array}$ & $\begin{array}{l}\text { Physically challenging } \\
\text { for both children and } \\
\text { old }\end{array}$ \\
\hline Social capital & $\checkmark$ no social capital & $\begin{array}{l}\text { lack of social } \\
\text { capital }\end{array}$ & $\begin{array}{l}\text { Both the age group has } \\
\text { no network / social } \\
\text { capital due to age }\end{array}$ \\
\hline $\begin{array}{l}\text { Intra-HH } \\
\text { relationship }\end{array}$ & - Absence of male member & $\begin{array}{l}\text { Lack of support } \\
\text { from kinship }\end{array}$ & Feel totally insecure \\
\hline $\begin{array}{l}\text { Weak State } \\
\text { agencies }\end{array}$ & - Police as a maastan & $\begin{array}{l}\text { lack of support } \\
\text { from the state }\end{array}$ & $\begin{array}{l}\text { more vulnerable than } \\
\text { other age group }\end{array}$ \\
\hline
\end{tabular}

Table 3. Selected indicators of Vulnerability by Marital Status

\begin{tabular}{|c|c|c|c|c|}
\hline $\begin{array}{c}\text { Selected } \\
\text { indicators of } \\
\text { Vulnerabilities } \\
\end{array}$ & Male & Female & Differentiations & Comments \\
\hline $\begin{array}{l}\text { Income/ } \\
\text { occupation }\end{array}$ & - & $\begin{array}{l}\text { - No } \\
\text { income / less } \\
\text { income } \\
\text { job opportunity } \\
\text { Less } \\
\text { ent on male } \\
\text { members }\end{array}$ & $\begin{array}{l}\text { Econo } \\
\text { mic crisis for the } \\
\text { total HH Lack of } \\
\text { economic } \\
\text { support for } \\
\text { female }\end{array}$ & $\begin{array}{l}\text { Absence of male } \\
\text { support is a big } \\
\text { crisis for female }\end{array}$ \\
\hline Shelter & & $\begin{array}{l}\text { - Homele } \\
\text { ss / less access to } \\
\text { shelter }\end{array}$ & $\begin{array}{l}\text { - Become } \\
\text { homeless or } \\
\text { burden of rent }\end{array}$ & $\begin{array}{l}\text { Women are more } \\
\text { vulnerable }\end{array}$ \\
\hline Infrastructure & $\begin{array}{l}\text { Burden } \\
\text { of reproductive } \\
\text { work: collect } \\
\text { water, cleaning, }\end{array}$ & $\begin{array}{l}\text { - Less } \\
\text { access to public } \\
\text { domain }\end{array}$ & $\begin{array}{l}\text { Childre } \\
\text { n particularly } \\
\text { girls are forced } \\
\text { to involve in }\end{array}$ & $\begin{array}{l}\text { Double burden for } \\
\text { children and girl } \\
\text { child lost the basic } \\
\text { opportunities in }\end{array}$ \\
\hline
\end{tabular}




\begin{tabular}{|c|c|c|c|c|}
\hline $\begin{array}{c}\text { Selected } \\
\text { indicators of }\end{array}$ & Male & Female & Differentiations & Comments \\
\hline & $\begin{array}{l}\text { child rearing and } \\
\text { cooking }\end{array}$ & & $\begin{array}{l}\text { reproductive } \\
\text { work }\end{array}$ & $\begin{array}{l}\text { life (education, } \\
\text { nutrition etc. }\end{array}$ \\
\hline Social capital & $\begin{array}{cc} & \text { Less } \\
\text { social prestige }\end{array}$ & $\begin{array}{l}\text { Less } \\
\text { social status } \\
\text { voice Less } \\
\cdot \text { access to Less } \\
\text { decision - } \\
\text { making process }\end{array}$ & $\begin{array}{l}\text { - Increas } \\
\text { ed threats of } \\
\text { violence } \\
\text { - Social } \\
\text { and economic } \\
\text { vulnerability }\end{array}$ & $\begin{array}{l}\text { Loosen network } \\
\text { due to insecure } \\
\text { land tenure-ship } \\
\text { and lack of income } \\
\text { and skill. }\end{array}$ \\
\hline $\begin{array}{l}\text { Intra-HH } \\
\text { relationship }\end{array}$ & $\begin{array}{l}\text { Physica } \\
\text { 1 and social } \\
\text { inconvenience } \\
\text { (absence of wife } \\
\text { and female } \\
\text { members of the } \\
\mathrm{HH} \text { ) }\end{array}$ & $\begin{array}{l}\text { Childre } \\
\text { n are neglected } \\
\text { due to mother's } \\
\text { 'double burden' } \\
\text { of work } \\
\text { Locial status and } \\
\text { power }\end{array}$ & $\begin{array}{l}\text { - FHH } \\
\text { more insecure } \\
\text { both socially and } \\
\text { economically. } \\
\text { ation Exploit } \\
\text { - } \\
\text { tion of children }\end{array}$ & $\begin{array}{l}\text { More violence and } \\
\text { instability } \\
\text { And children are } \\
\text { more vulnerable } \\
\text { section among the } \\
\text { population }\end{array}$ \\
\hline $\begin{array}{l}\text { Weak State } \\
\text { agencies }\end{array}$ & - & $\begin{array}{l}\text { - Harass } \\
\text { ment of Maastan } \\
\text { - Less } \\
\text { support from } \\
\text { police }\end{array}$ & $\begin{array}{l}\text { More } \\
\text { prone to } \\
\text { harassment }\end{array}$ & $\begin{array}{l}\text { Lack of access to } \\
\text { justice }\end{array}$ \\
\hline
\end{tabular}

\section{Findings and Discussion}

Who are the Urban Poor?: Livelihood Vulnerability in Begultila

Samad Mia, a slum dweller in Begultila opined:

We all are from different bustees (slum), when it was announced that all our bustees will be evicted we had no place to go except the road. Then I went to the office to Bastuhara Shamobay Samiti central office to meet our president to request him to do something for us. We were told to go to the High Court front yard to get the attention of the authority. Then we stayed there for seven days. Meanwhile, we were driven by the police by force and if refused beaten mercilessly. But we continued to stay. Then after a few days we were transported by trucks to Begultila.

There are various definitions of poverty, but it is important to know how the poor themselves perceive poverty in the context of urban slums in Dhaka. The poor slum dwellers of Begultila listed a wide range of issues in expressing their perception of poverty (Rakodi \& Lloyd, 2002). There are similarities and 
dissimilarities among the numerous groups (male, female, children, FHH and beggar) in their perception of poverty. The slum dwellers in categorized the total population into three broad groups: Less Poor (category 1), More Poor (category 2) and the Poorest (category 3). While the degree of poverty, economic soundness played the key role in their self-grouping, to the slum dwellers did not consider economic as the sole indicator. The grouping also depended on the social stature of the individual. Based on this, the "Less Poor" group also included those who are poor but are the leaders or respectable persons in the slum. They explained, "We cannot put the socially prestigious persons in a lower group no matter whether they are rich or not. They are poor due to unemployment, more dependents in the households, and because they cannot go for less prestigious jobs like daily laborers. They would rather be starving with the whole family but will not go for odd jobs and lose social prestige". This social mindset reflects the traditional society that exists in Bangladesh. The researcher sub-categorized the "poorest" into two separate groups: the beggars (category 4) and the socially vulnerable women (category 5) because of their distinct social identities.

The livelihood pattern of Begultila presented below is a grossly simplified attempt to analyse and discuss livelihood vulnerability in the slum through five indicators (occupation, shelter, infrastructure, social capital and intra household relationships) of the asset vulnerability framework (Chambers \& Conway, 1992; Moser, 1998; Carney, 1998; Walker et al., 2002; Rakodi \& Lloyd, 2002; Shaffer, 2008; Shepherd \& Hulme, 2003; Stevens, 2003).

\section{Occupation}

The occupational pattern of the Begultila population presented below was used to analyse and discuss the labour situation in the slum. The list of the occupational choices/characteristics of the men and women in Begultila slum are as follows:

Common Occupation of the Male

\begin{tabular}{|l|l|l|}
\hline \multicolumn{1}{|c|}{ Occupation } & \multicolumn{1}{|c|}{$\begin{array}{c}\text { AV Category } \\
\text { (Asset Vulnerability } \\
\text { framework, see section 1.2) }\end{array}$} & $\begin{array}{c}\text { Percentage } \\
\text { (arbitrary) of } \\
\text { people involved }\end{array}$ \\
\hline Overall Male Category (Adult, 20+) & $45-50$ \\
\hline Rickshaw/Van Puller & Insecure & $25-35$ \\
\hline Day Labourer & Insecure &
\end{tabular}




\begin{tabular}{|l|l|l|}
\hline \multicolumn{1}{|c|}{ Occupation } & \multicolumn{1}{c|}{$\begin{array}{c}\text { AV Category } \\
\text { (Asset Vulnerability } \\
\text { framework, see section 1.2) }\end{array}$} & $\begin{array}{c}\text { Percentage } \\
\text { (arbitrary) of } \\
\text { people involved }\end{array}$ \\
\hline Petty Business & Secure & $20-25$ \\
\hline Services & Secure & Around 5 \\
\hline Age Group 18-20 & Secure & 30 \\
\hline Garment Worker & $15-20$ persons \\
\hline Age Group 12-18 & 30 persons (approx.) \\
\hline $\begin{array}{l}\text { Helper/Worker at tea stalls, } \\
\text { rickshaw garages, factories }\end{array}$ & Secure \\
\hline Disabled (Cannot work) & Insecure
\end{tabular}

Common Occupation of the Female

\begin{tabular}{|l|l|l|}
\hline Occupation & AV Category & Percentage (arbitrary) \\
\hline \multicolumn{2}{|l|}{ Overall Female Category (Adult, 20+) } & 30 persons \\
\hline Sewing and Embroidery Work & Insecure & 35 \\
\hline Garment Worker & Secure & $4-5$ \\
\hline Petty Business & Secure & $25-30$ persons \\
\hline Domestic help & Insecure & 70 \\
\hline Age Group 18-20 & Secure \\
\hline Garment Worker & Insecure \\
\hline Age Group 12-18 & Insecure & \\
\hline Student/Household help & Insecure & 70 persons (approx.) \\
\hline Sewing and Embroidery Work
\end{tabular}

Men are mainly employed as daily labourer (construction worker, earth cutting, etc.), rickshaw pullers, vendors, and petty business. This situation, therefore, is indicative of differences in poverty and vulnerability and the assumption that "Poorer HHs has more than one person engaged in productive labour" also is valid for Begultila. The common scenario is that the households that are large, but small in earning members are the poorest and most vulnerable.

Most females in Begultila identified themselves as vulnerable; a large number of women have husbands do not work regularly or are absent, male family members 
who do not earn and those that are highly non-cooperative about overall household expenditure. Once again, a lack of opportunity for women's employment, especially those with young children are identified as the most vulnerable group in the slum.

Adolescent girls, on the other hand, have the relative freedom of and prefer to work in the many garment factories of Dhaka city. One of the motivational forces behind this is to save some money for their own marriage or to relieve their parents' economic burden. Likewise, parents of girls, who are not employed or too young to be employed, are constantly tense about their safety, owing to the insecure slum environment.

\section{Irregular Income of Husband Causes Poverty}

Kohinur (25) left her job in a garment factory after she became pregnant. She complained, "Our condition is really bad because of no income. My husband does not work regularly. We borrow money most of the time. So, we have no development; rather the situation is deteriorating day by day".

Women are often poorer because husbands do not work regularly. Therefore, to maintain their families, they are forced to take loans from others. However, as soon as the husbands go back to work temporarily the women find themselves under pressure to repay the loans and fall back into the cycle of poverty and economic instability. Additionally, Female Headed Households (FHHs) are the poorest and most vulnerable in the slum and children of these households are forced to engage in informal work like collecting firewood or leaves and helping in shops or restaurants.

Begging is the most common occupation, especially amongst the poorest slum households. As per interviews none of the participants admitted to "enjoy" begging. Most of them only resorted to begging when they perceived that no other opportunities existed; the label of 'beggar' implies extremely low social status. For instance, Morium (25), a mother of three young children, deserted by her husband, begs for their living, and earns around Tk 200 a day. She detests begging because she is abused every day for 'not finding work' when she is physically able. Morium knows no other options, "If I work full time, who will take care of the children? My mother works all day in a restaurant, washing utensils and grinding spices".

\section{Shelter}


A slum leader said:

we are facing poverty in every possible way. We have various problems, but the basic problems are shelter, education, and health. The Government said several times they would give us the land. But they are not implementing the promise; but we are still hoping and waiting. If we get a permanent residence here, then we would be able to manage a better livelihood and it would have been helpful for my next generation.

Begultila slum was created overnight by the government by evicting several slums in Dhaka city. The land is owned by the government. So, there is no possibility of renting a house. The dwellers were promised by the government (and political parties) that they would get legal tenure of the land, but this seems highly unrealistic at this point in time; something as drastic would require a major shift in both policy and the government's approach to poverty the poor. Shelter, therefore, remains a prominent source of vulnerability of the slum dwellers; if those that have their own houses in Begultila do not consider it to be an asset because of there is a constant fear of eviction.

\section{Infrastructure}

Poor sanitation and water availability are, according to many, the most serious problem in Begultila. The slum dwellers spend a significant amount of time collecting water from distant places; women are the prime victims of the situation. The situation of slum sanitation is even worse. The number of latrines is inadequate and keeping them clean continues to be a challenge. People are paying to keep them clean, but they commonly complained about the mismanagement of the slum committee in accomplishing this urgent task. The sanitation situation is a problem for all, but especially for women, the handicapped and elderly people. Khoshed Alam Mollah, a slum dweller added, "The number of latrines is less compared to the population in the slum. Sometimes people cannot wait and soils their clothes". Similarly, there is a serious lack of public educational services; for instance, there is no government primary school near Begultila.

\section{Social Capital (Network)}

Khadiza, a slum dweller frustrates and mentioned, "My brother-in-law is feeling embarrassed to be a relative of us as we are now living in a 'bustee'. Earlier we used to live in a rental house and his family had a good relationship with us". 
There are various instances of degrading social networks that accompany settling down in Begultila. The AV assumption, reciprocal relationships and social networks are frayed in urban contexts, and more applicable in the case of intrahousehold relationships than social networks. The assumption, number of Community Based Organizations (CBO) present in the community is an indicator of social capital and the composition patterns of these organizations are good indicators of heterogeneity in vulnerability amongst the urban poor. The Slum Committee has been in existence since the establishment of Begultila, but the slum dwellers do not seem to have faith in the committee or its leadership. For coping with crises, people tend to depend on their neighbours.

\section{Intra-Household Relationship}

Khorshed, (husband of Khadija) a resident of the slum says to his wife Khadija:

I have only one 'pat' (stomach) to feed but you have four (three children and Khadija herself); and you are responsible for all of them". Khadija added, "I look for the job in many places but in vain. No one likes to have a maid with little kids. I cannot go to other work. Who will take care of my little child? After my husband left me, I have faced real difficulties in my life. I forced myself to go for begging as I do not have another alternative.

The intra-household relationship has been frayed in several instances due to growing poverty. Khadija (30) developed a bad relationship with her husband ever since moving to Dhaka. Their relationship was good while they lived in the village she recalled. She said, "now we are using abusive languages at each other, but earlier we would never do that". She came to Dhaka because of misunderstanding with her in laws.

In Khadija's case, the perception of poverty is related to her husband's behaviour. Khadija mentioned that, "if my husband works regularly, I will not have any crisis economically and or trouble with the intra-household relationships." She stated that "my husband does not work, and he is indifferent to the family's needs". She could not reach out for any better source of earning since her children are too young to be left home alone. She admitted that she wanted a home to settle down in.

Intra household violence is also a significant indicator that increases women's vulnerability. Shaynnessa complained that her husband was not supporting her. She stated that he had married several times and lived in India, illegally, for three 
years. He used to come and stay with her for a few days throughout the year and always asked for money; if she ever refused him, he used to beat her.

Female Headed Household (FHH) consider poverty, not only as a material crisis, but also as an emotional crisis. They think that they have no one to support them financially or otherwise. For example, they have no one to call on for repairing the house, or for any sort of 'men's work', or to take the sick children to the doctor or to provide support in all sorts of personal crisis. In Begultila, many young women are involved in begging as a profession. They cannot pursue other full-time work because of their children.

A household with two working parents may not always be the ideal situation for the children in the slum. Both Malek and his wife are working and sent their children to school but were forced to pull them out soon afterwards. "None of our children even completed class IV," they regretted.

The experience of poverty is quite different based one's age and gender. Age is a critical factor as young girls and elderly women experience poverty differently than other members of the urban poor. For example, children those who are only earning member of the household's experience poverty utterly differently; the assumption that "women working outside the home and an increased reliance on child labour are signs of deterioration in the HH economy" in general holds valid. Rubel (11 years old) works in a curtain shop as an assistant cum tea boy New Market is the main earner of the household. He said, "I help the tailor to hold the curtain cloth straight, bring tea, sweep and wipe the floor. I wish to study now. But who will bear the expenses of my livelihood if I don't work?". Most of the time, parents of these children quarrel with each other and the husband goes off and gets married again. As a result, they are forced into begging. According to Rubel "the poorest in the slum are the boys or girls who do not have fathers". $\mathrm{He}$ mentioned that said the absence of a father is the main cause of his poverty. Overall, most female children work inside the house in comparison to male children, like Rubel, who work outside the home.

Age is an important factor in terms of urban poverty. The elderly population also like children, experiences an acute lack of support. Anowara Begum (60) came to Dhaka when she was very little and was forced to work as a domestic help from a young age. But now she begs for a living since she is unable to work. She lives with her elderly husband and a 10-year-old grandchild as her daughter got 
remarried and left the son from her first marriage with them.

Lack of old age security elderly, particularly women become more vulnerable as Kulsum Bibi (55) and Anowara (60) think that their situation is bad as an old person. They did not get any work and, as a result, they are now begging. Kulsum Bibi, a beggar, said that she needs a source of income and a place to live. Kulsum Bibi is a widow and begging to support herself. She worked as a daily labourer and sweeper. But she could not continue because of old age and left Mohammadpur where she used to work as a sweeper. She has two daughters. Her eldest daughter does not support her. Instead, she demands support from her. Jayera Khatun (60), a widow, feels shy to go for begging. She collects natural vegetable leaves to sell/eat. Her sons help her, but they cannot stay together because of misunderstanding. She is also hoping that once she would get a land here that she would leave for the future of her sons.

\section{Frail State Agencies Perpetuate Poverty}

Morium (25), a mother of three young children, deserted woman living in Begultila. She had set up a 'peeta' [sweets] shop inside the slum but was unable to continue paying toll taxes to the mastaans who, along with other residents, often ate at her shop but did not pay. She said with anger and frustration:

In the slum, the more powerful people do not pay. People like me [female, very poor and without a male support] can say nothing. On top of that, we have to pay toll to all these people, boys, mastaans, and police for various activities. It just became too difficult for me to continue a small business.

A common experience for slum residents is the payment of tolls (bribes) to various influential people, to maintain their livelihoods. The Mastaan (hooligan) system in Bangladesh is the most extreme that was identified in the research (Joshi, Fawcett, \& Mannan, 2011; Mannan 2011). In Bangladesh, 'greater' indifference of the government to the existence of the urban poor has led to all slums being under the control of a group of men who appoint themselves as the leaders, referred to commonly as mastaans. The mastaans have different levels of authority and hierarchy among themselves, depending on their economic and political networks (Mannan, 2011).

According to one Begultila resident, "Whoever has paid the money wins the 'shalish' (justice)." There are many incidents of irrespective of age, gender and 
marital status of the residents who were victimized and have faced injustice. For example, Mouri (single and in her 20s), in Begultila, was forced to walk around the slum with a garland of shoes around her neck after a fight with a richer neighbour, with whom the leaders took sides. Her mother, who is also divorced, did not protest because the leaders are too strong to protest.

In Bangladesh, men link poverty to poor networking, lack of jobs and loss of social prestige in the public sphere, while women link it to the absence of support of a male guardian (Rashid, 2004), be he a husband, son or uncle. Men do not see women as integral to their poverty situation, whereas women see men as integral to their survival, thus reflecting the gendered structure of society and the vulnerability of women (Mannan \& Rashid, 2004).

Thus, the major finding of the field data demonstrates that the vulnerability of livelihoods perpetuates poverty among the urban poor and that the livelihood vulnerability is influenced by age, marital status, and gender in Begultila slum.

How marital status, age and gender are related to urban poverty?

According to the above discussion experience of vulnerability in the life of slum dwellers is quite a dominating feature. A common finding was the number of femaleheaded households in the slums continue to be under reported and difficult to categorize. Marriage is both socially, culturally, and religiously proscribed in Bangladesh, but shame and social stigma related to marital disruption results in under reporting (Salway, Rahman, \& Jesmin 2003; White, 1992; Rozario, 1992; Khan, Townsend, \& D'Costa, 2010) In the anonymous environment of urban slums, marriage breakups are difficult to stop as families and relationships are fractured and 'community' in that sense does not exist. Therefore, men are less likely to experience disapproval and do not fear social sanctions as they would in rural areas. For women, the only source of approved status is through marriage and motherhood (Salway et al., 2003). For many, the lack of male kin/spousal support leaves them in difficult situation both socially, culturally, and physically. In distinguishing between the relatively better off and the most vulnerable, females, particularly female headed households and elderly stand out as the most insecure in the slums. Many of the poorer female-headed households face multiple constraints with poverty, class and patriarchy oppressing them (Wood, 1998).

While economic and social conditions worsen for many, attitudes are defined by traditional cultures of patriarchy and purdah. Many of the women believe that 
the husband's role is that of the breadwinner, which ideally means that indoor, household work is for women and outdoor work is for men (Salway et al., 2003). The urban labour market does offer employment opportunities for women as well as men. However, job sectors, levels and locations remain defined by gender. Wood (1998) points out that most of the jobs open to women are as manual workers in the garment factories or as house-help.

Hasna, in Begultila slum, (mother of three children) has been working outside the home after her husband left her. Currently, she works in a nearby factory and has accepted a very low salary, only because she is able to come home and look after her daughters at lunch time. Women with babies or young children who do not have support at home, are forced to bring their children/babies with them while they work. Women with babies have to stop to breast-feed, yet employers complain of 'tired, crying babies' and are reluctant to re-employ such women. Women spoke of being physically and emotionally exhausted by the end of the day; but with few options in the scene and a culture of absconding husbands, this is often the only way of managing their households.

Hence, absence of male support is very crucial to the female in Begultila slum. The exercise of power and availability of opportunities is heavily gendered in the context of Bangladesh's culture [Kabir, 1998; Salway et al, 1998]. It is often the men [be it sons, husbands, male guardians] who establish the networking and create social capital for themselves and their families [See, Rashid, 2004; Wood, 1998]. Thus, females [abandoned and without any male support] and the elderly tend to be left out of these networks and relationships. Children also feel very insecure if the father is absent in the household. Corruption of state agencies and threats from local mastaans are the common feeling of vulnerability among the slum dwellers irrespective of age, marital status, and gender (See box: 1). 


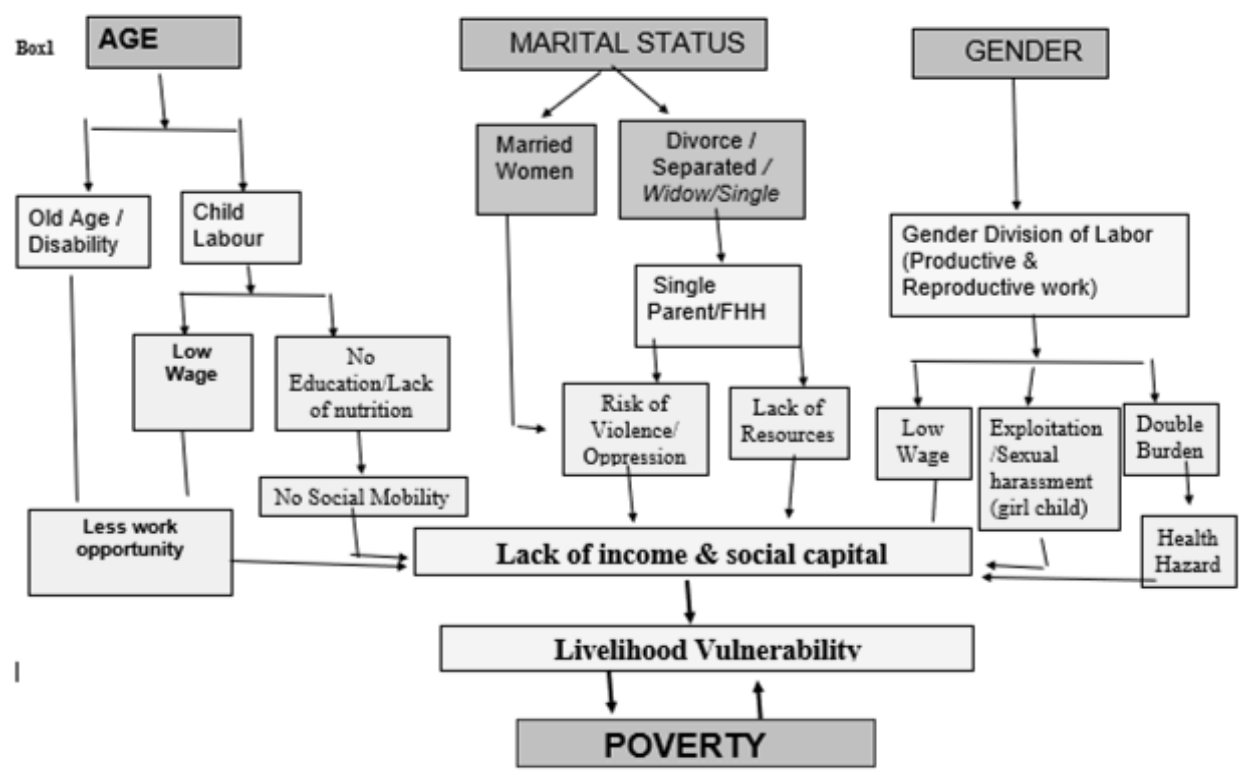

\section{Concluding Remarks and Way Forward}

To understand the state of poverty it is important to look at non-economic factors as it has a very strong role in enhancing vulnerability among the urban poor particularly with children, elderly and women. Age remains a crucial factor in understanding poverty; children, young girls, in particular, have been deprived from education and food and forced to bear the burden of the reproductive work or forced to enter the job market. However, both these age groups (elderly and children) face a lack of work opportunity and are paid low wages, which increases more livelihood vulnerability.

Marital status is a significant component of livelihood vulnerability that can result in acute poverty. Married women are dependent on their husbands both economically as well as for their social status. Hence, they are more prone to domestic violence and having less dignity in life. However, other than married women (divorced, widows etc.) are also in a disadvantageous position. They not only carry a double burden of work, both in the private and public spheres, but they lack social capital and resources turns their position even worse.

This paper has indicated that both physical and emotional vulnerabilities have a crucial impact on the livelihood pattern of the slum dwellers of Begultila. In addition, weak state agencies failed to play the appropriate role, which makes the 
helpless slum dwellers even more vulnerable to mastaans.

Finally, this study incorporates some new insights about urban poverty in relation to livelihood vulnerability by highlighting diverse experiences of urban poor women and children, which renders them the most vulnerable group within the slum. Thus, gendered perspectives of livelihood vulnerability are imperative to understanding the lives of urban poor women and constant threats to their wellbeing that perpetuates their poverty. Policy action guided by the feminization of poverty in slums is a crucial dimension of urban poverty that demands urgent attention. The following illustrates some policy implications to address this issue:

- The rapid growth of the largely unplanned urban sector is a matter of key policy concern. The Bangladesh Government has to understand that Dhaka, a mega city cannot function without a large working class. Thus, urban policy must be revised to reduce the vulnerability of the 'invisible' urban poor in general and women in particular - both of whom are significantly contributing to the economic growth of the country.

- One of the prime aims of the Sustainable Development Goals (SDGs) is making urban areas, particularly cities secure, resilient, and sustainable. This analysis indicates that unless and until the technical, financial, and ethical discrepancies relating to the livelihood vulnerability of the urban poor are not rethink, there is little scope to achieve the goals of SDGs for all. Corresponding to these goals it is urgent for government agencies, policy makers, city planners, academics, development partners and civil society organizations alike to collaborate effectively and take necessary and effective action to address these issues.

- Given the feminization of migration, and the data collected, an increase in educational and employment opportunities for women and girls are recommended along with safe communal housing for working women and increased efforts to ensure their safe mobility in cities. Likewise, it is essential to include the priorities and welfare of the urban poor in government planning and budget.

- Lastly, it demands strong commitment and long-term sustainable efforts to face the challenges presented by urban poverty on a holistic way; Bangladesh still has a long way to go when it comes to mainstreaming gender policy, particularly in relation to the urban poor. 


\section{References}

Afsar, R. (1998). Rural-urban migration and development: evidence from Bangladesh. In R. E. Bilsborrow (Ed.), Migration, urbanization, and development: new directions and issues (pp. 319-356). Heidelberg: Spring Netherlands.

Afsar, R. (2000). Rural-Urban Migration in Bangladesh: Causes, Consequences, and Challenges. Dhaka: The University Press Limited.

Carney, D. (Ed.) (1998). Sustainable Rural Livelihoods- What Contribution Can We Make? London: Department for International Development (DFID).

Chambers, R., \& Conway, G. R. (1992). Sustainable Rural Livelihood: Practical concepts for the 21 st Century. Brighton: Institution for Development Studies, University of Sussex.

Ellis, F. (1998). Household strategies and rural livelihood diversification. Journal of Development Studies, 35(1), 1-38. doi:10.1080/00220389808422553

Farrington, J., \& Robinson, M (2006). Introduction: Meeting the Challenges to Growth and Poverty Reduction. Development Policy Review, 24(s1), s3-12.

Islam, N. (1996). The Urban Poor in Bangladesh. Dhaka: Centre for Urban Studies.

Islam, N., Haq, Z. A., \& Rahman, Q. (1996). Study of Urban Poverty in Bangladesh. Final Report: Volume 1. Survey Results. Dhaka: Government of Bangladesh, Planning Commission \& Asian Development Bank.

Joshi, D., Fawcett, B., \& Mannan, F. (2011). Health, hygiene and appropriate sanitation: experiences and perceptions of the urban poor. Environment and Urbanization, 23(1), 91-111. doi:10.1177/0956247811398602

Joshi, D., Fawcett, B., \& Morgan, J. (2005). Sanitation for the urban poor: Whose choice, theirs or ours? London: Engineering for Development, University of Southampton and Department for International Development (DFID).

Kabeer, N. \& Mahmud, S. (2004). Globalization, gender and poverty: Bangladeshi women workers in export and local markets. Journal of international development, 16(1), 93-109. doi:10.1002/jid.1065

Kabir, A. (1998). Shocks, Vulnerability, and Coping in the Bustee Communities of Dhaka. Discourse. A Journal of Policy Studies, 2(2), 120-146.

Khan, M. E., Townsend, J., \& D’Costa, S. (2010). Behind closed doors: A qualitative study of sexual behaviour of married women in Bangladesh. Culture, Health \& Sexuality, 4(2), 237-256.

Mahmud, S. (1997). Women's work in urban Bangladesh: is there an economic rationale? Development and Change, 28(2), 235-260.

Majumder, P. (1996). Health Impact of Women's Wage Employment: A Case Study of the Garment Industry of Bangladesh. The Bangladesh Development Studies, 24(1/2), 59-102.

Mannan, F. (2011). Mastanocracy, Violence and Gender in Dhaka Slum. Dhaka: University Press Limited.

Mannan, F., \& Rashid, S.F. 2004. The Heterogeneity of Urban Poverty (Unpublished research report). University of Southampton, United Kingdom.

Moser, C. O. (1998). The Asset Vulnerability Framework: Reassessing Urban Poverty Reduction Strategies. World Development, 26(1), 1-19. 
Rakodi, C., \& Lloyd, T. J. (2002). Urban Livelihoods, A People- Cantered Approach to Reducing Poverty (pp 3-34). London: Earthscan Publication.

Rashid, S. F. (2004). Worried Lives: Poverty, Gender and Reproductive Health for Adolescent Women in a Slum in Dhaka, Bangladesh (Unpublished PhD thesis). The Australian National University, Australia.

Rozario, S. (1992). Purity and communal boundaries: women and social change in a Bangladeshi village, The Australian and New Zealand Journal of Sociology, 29(2), 261-263. doi:10.1177/144078339302900208.

Salahuddin, K. (1997). Women and Poverty. Dhaka: Women for Women.

Salway, S., Rahman, S., \& Jesmin, S. (2003). A Profile of Women's Work Participation Among the Urban Poor of Dhaka. World Development, 31(5), 881-901.

Shaffer, P. (2008). New Thinking on Poverty: Implications for Globalisation and Poverty Reduction Strategies. Working Paper Series No. 65. London: Department of Economic and Social Affairs, (DESA).

Shepherd, A., \& Hulme, D. (2003). Conceptualizing Chronic Poverty. World Development, 31(3) 402-423.

Stevens, L. (2003 April 7-9). Chronic poverty in urban informal settlements in South Africa: combining quantitative and qualitative data to monitor the impact of interventions [Paper presentation]. Staying Poor: Chronic poverty and Development policy Conference, Institute for Development Policy and Management, University of Manchester, Manchester, UK.

United Nations Population Fund (UNFPA). (2016). Annual Report 2016: Millions of lives transformed. New York: United Nations Population Fund.

Walker, J., Ramasut, T., \& Farrington, J. (2002). Sustainable Livelihoods Approaches in Urban Areas: General Lessons, with Illustrations from Indian Cases. Working Paper No. 162. London: Overseas Development Institute.

White, S. C. (1992). Arguing with the crocodile: gender and class in Bangladesh. Dhaka: The University Press Limited.

Wood, G. (1998). Investing in networks: Livelihoods and social capital in Dhaka slums. Workshop on Urban Livelihoods Study. A Dissemination of Findings 1998. Organized by Institute of Development Policy Analysis and Advocacy (IDPAA) at Proshika. Dhaka: Bangladesh.

World Bank \& Bangladesh Centre for Advanced Studies. (1998). Bangladesh 2020: A long-run perspective study. Dhaka: The University Press Limited.

World Bank. (2007). To the MDGs and Beyond: Accountability and Institutional Innovation in Bangladesh. Washington DC: World Bank. 